\title{
Employability As A Complex Problem
}

La empleabilidad como problema complejo

Empregabilidade como um problema complexo

\section{Luisa Fernanda Hernández Corredor ${ }^{1}$ Ronald Sneyder Beltrán Martínez ${ }^{2}$}

Received: January $15^{\text {th }}, 2020$

Accepted: April $13^{\text {th }}, 2020$

Available: May $4^{\text {th }}, 2020$

How to cite this article:

L. F. Hernández Corredor, R. S. Beltrán Martínez "Employability as a Complex Problem,"

Revista Ingeniería Solidaria, vol. 16, no. 2, 2020. doi: https://doi.org/10.16925/2357-6014.2020.02.01

Artículo de investigación. https://doi.org/10.16925/2357-6014.2020.02.01

1 Facultad de Ingeniería. Universidad Distrital Francisco José de Caldas, Bogota, Colombia.

ORCID: https://orcid.org/0000-0002-2801-7133

Email: Ifhernandezc@correo.udisrital.edu.co

2 Facultad de ingeniería. Universidad Distrital Francisco José de Caldas. Colombia.

ORCID: https://orcid.org/0000-0003-3641-8989

E-mail: rsbeltranm@correo.udistrital.edu.co 


\section{Abstract}

Introduction: This article is developed within the framework of the Emple-ap project, coordinated since 2018 by the Universidad Distrital Francisco José de Caldas in Bogotá.

Problem: Recent graduates of higher education face a problem of employability that is affected by multiple interdependent and changing variables, actors and contexts, which makes it more complex in nature. However, the problem is usually approached from a simplistic perspective that prevents the construction of proposals that generate a high impact in practice.

Objective: The objective of this research is to generate a proposal to study the problem of employability from the perspective of complex thinking.

Methodology: The methodology used is based on a literature review and a panel of experts through structural analysis.

Results: The predominance of the simplistic approach in the understanding of employability is made evident, being expressed in a limited set of variables and generally focused on the professional. In addition, the structural analysis makes it possible to highlight the high interdependence existing between the variables that encompass different actors and contexts.

Conclusions: It is necessary to redirect the approach from which employability is studied, recognizing that the problem must be tackled globally and is in a state of constant change, in order to generate dynamic solutions that adapt to it.

Originality: This research offers a first proposal to understand employability as a complex problem, emphasizing the interdependence of variables.

Limitations: The presented results are too recent to make a generalization and although the proposed variables were verified in the panel, they have not yet been validated.

Keywords: Employability, simple problem, complex problem, employability variables

\section{Resumen}

Introducción: El presente artículo se desarrolla dentro del marco del proyecto Emple-ap coordinado desde 2018 por la Universidad Distrital Francisco José de Caldas en Bogotá.

Problema: Los recién egresados de educación superior se enfrentan ante un problema de empleabilidad que se ve afectado por múltiples variables, actores y contextos interdependientes y cambiantes, que conlleva a que posea una naturaleza compleja; sin embargo, usualmente el problema es abordado desde una perspectiva simplista que impide la construcción de propuestas que generan un alto impacto en la práctica.

Objetivo: El objetivo de esta investigación es generar una propuesta de estudio del problema de la empleabilidad desde la perspectiva del pensamiento complejo.

Metodología: La metodología empleada se fundamenta en revisión de literatura y panel de expertos a través de análisis estructural.

Resultados: Se evidencia la predominancia del enfoque simplista en la comprensión de la empleabilidad, siendo expresado en un conjunto limitado de variables y generalmente centradas en el profesional. Además, el análisis estructural permite evidenciar la alta interdependecia existente entre las variables que engloba a diferentes actores y contextos.

Conclusiones: Es necesario redireccionar el enfoque desde el cual se estudia la empleabilidad, el cual reconozca que el problema debe ser abordado de forma global y reconociendo su constante cambio, con el fin de generar soluciones dinámicas que se adapten al mismo. 
Originalidad: A través de esta investigación se ofrece una primera propuesta para comprender la empleabilidad como problema complejo, haciendo énfasis en la interdependencia de las variables.

Limitaciones: Los resultados presentados son tempranos para realizar una generalización y si bien las variables propuestas fueron verificadas en el panel, aún no han sido validadas.

Palabras clave: Empleabilidad, problema simple, problema complejo, variables de empleabilidad.

\section{Resumo}

Introdução: Este artigo foi desenvolvido no âmbito do projeto Employ-ap coordenado desde 2018 pela Universidade Distrital Francisco José de Caldas, em Bogotá.

Problema: Os recém-formados no ensino superior enfrentam um problema de empregabilidade que é afetado por múltiplas variáveis, atores e contextos interdependentes e variáveis, o que o torna de natureza complexa; no entanto, o problema geralmente é abordado a partir de uma perspectiva simplista que impede a construção de propostas que geram um alto impacto na prática.

Objetivo: 0 objetivo desta pesquisa é gerar uma proposta para estudar o problema da empregabilidade na perspectiva do pensamento complexo.

Metodologia: A metodologia utilizada é baseada em revisão de literatura e painel de especialistas por meio de análise estrutural.

Resultados: É evidenciada a predominância da abordagem simplista no entendimento da empregabilidade, sendo expressa em um conjunto limitado de variáveis e geralmente focada no profissional. Além disso, a análise estrutural permite destacar a alta interdependência existente entre as variáveis que abrangem diferentes atores e contextos.

Conclusões: É necessário redirecionar a abordagem a partir da qual a empregabilidade é estudada, que reconhece que o problema deve ser encarado globalmente e reconhecendo sua constante mudança, a fim de gerar soluções dinâmicas que se adaptem a ele.

Originalidade: Esta pesquisa oferece uma primeira proposta para entender a empregabilidade como um problema complexo, enfatizando a interdependência de variáveis.

Limitações: Os resultados apresentados são bastante novos para fazer uma generalização e, embora as variáveis propostas tenham sido verificadas no painel, elas ainda não foram validadas.

Palavras-chave: Empregabilidade, problema simples, problema complexo, variáveis de empregabilidade

\section{INTRODUCTION}

During the last years, recent graduates of higher education programs face a problem of employability, mainly when they remain unemployed for a prolonged period of time or when they work in most cases in labor fields that are not related to their level of education or studied career [1][2]; thus affecting their personal and professional development, and also generating negative effects for a country at the social and economic level. 
This problem is manifested as an effect of the vertiginous changes that society has undergone during the last decades, at the social, technological, political, economic level [3] etc.; an example of these changes being, among others, the gradual massification of higher education in the last decades [1] [4] [5] [6] and the rapid technological advances that have facilitated the globalization of the economy [7].

These implications make employability an issue that concerns different actors such as graduates, higher education institutions (HEIs), government, society and business [8] [9] and therefore constitutes the object of study of different disciplines [10] [11] in which it is recognized that employability is a problem affected by a great number of dynamic and interrelated variables, which are linked to both the individual and the context [12] [13] [14].

The great number of interrelated variables that affect employability and that manifest themselves in collective behaviors that characterize the problem in different environments and contexts, allow us to suppose that their study may be approached from the theory of systems, and therefore can be understood as a simple system and consequently treated from reductionism or understood as a complex problem and consequently recognize the interdependence of a large number of variables. In Section 2.1 the description of simple systems and complex systems is expanded.

When reviewing the literature around the different approaches to employability and alternatives to provide solutions, it can be said that they have been made from a simplistic or reductionist approach to the system, because although it is recognized that it is affected by a big number of variables, its interdependence is unknown.

Usually in the literature, there are approaches that affirm that employability refers to the competences of the individual [11], or to the practices carried out by HEls, or to the conditions of the labor market, and consequently specific actions are proposed for each of these variables. However, the actions carried out have not shown a high level of impact in solving the problem, and are even insufficient in practice, see for example [13] [14] [15] [16].

This research suggests that an alternative to the employability problem is to approach it as a problem or complex system that permanently changes; that means, it does not follow deterministic logic as its behavior does not depend on one or some variables, but arises from the interdependence between a large number of variables, actors and contexts difficult to predict and control. From this perspective, employability is understood in this paper as the employment opportunities that a person has and that emerge from the interdependence between different actors (individual, state, company, society), variables and contexts. 
This paper aims to provide evidence of the predominance to date of understanding the employability of recent graduates as a simple problem and to present a reflection for an approximation to their understanding as a complex problem.

For the development of the work, the first part presents a conceptualization of the attributes that characterize a simple and complex problem, as well as some thoughts refering to the different ways in which employability has been understood. After this, the methodology used and the findings are presented. Finally, the conclusions and future lines of research are presented.

\section{RESEARCH BACKGROUND}

To date there is no consensus on the definition of employability. Multiple definitions can be found in the literature that include, to a greater or lesser extent, a series of individual and contextual factors. Nevertheless, a big amount of theory can be found that relates employability to the development of a set of attributes, skills, capacities or competencies [11], thus emphasizing the characteristics linked to the individual.

The DOTS model, proposed in 1977 by Law and Watts, is based on a series of aspects that prepare students for the world of work, highlighting the following elements: learning decisions, knowledge of opportunities, learning transition and self-awareness [15]. Likewise, Knight and Yorke [22] proposed a model known as USEM, which is developed in four aspects: comprehension, skills, belief in effectiveness and metacognition, emphasizing the beliefs of effectiveness and their own theories, since they determine the ability of an individual to assume errors, persist and solve problems.

However, in contrast to this approach, some perspectives have been adopted to transform the idea of involving only the graduate to involve other actors in employability. In particular, Forrier and Sels [14] refer to employability as "the individual possibility of work in the internal and external labour market", indicating that it depends on the capacity and disposition of an individual and on contextual factors. Based on this, they identify a set of variables and propose a model that focuses on the process of employability, showing the variables that influence the possibility that a person has in the labour market. The variables they identify are: the labor market position, capital movement, ease of movement, context, transition, willingness to move, shock events, activities that maintain or improve your capital movement, and opportunities and willingness to maintain and improve your movement capital. A similar perspective is adopted by McQuaid and Lindsay [13] in criticizing the simplistic conception of employability by various authors. In this way, they classify the factors 
that affect them, which they classify into: individual factors, personal circumstances and external factors.

Consequently, a dynamism originates when speaking of the concept of "employability", which generate alternative positions to the initially proposed models. Dacre Pool and Sewell specifically criticize the USEM model by indicating that it is too academic and that its comprehension by students and parents is not easy. They also call out the simplicity of the DOTS model. Based on these models, they propose a new one called CareerEDGE, based on the development of a set of elements: knowledge, experience, generic skills, career development learning, general skills and emotional intelligence, which in turn allow for a reflection upon and evaluation of these experiences to obtain higher levels of self-efficacy, self-confidence and self-esteem, thus increasing the employability of the individual.

At the same time Fugate [24] adopts a dispositional approach, in which he studies employability as a set of personal characteristics that allow it to adapt to laboral and professional environments. While this approach focuses on the individual, they offer a more precise and comprehensive definition than other authors [25]. The model proposed by these authors uses the following key elements: openness to changes in work, work and professional resilience, work and professional proactivity, career motivation and work identity.

For a greater interpretation and extension of the concept, in diverse studies the notions of employability are identified by Forrier, Verbruggen, and De Cuyper [26] describing them as: transitions of work, movement of capital and perceived employability; and they carry out a study in which they integrate them. From this, they state that work transitions increase movement capital, which improves the perception of employment, which in turn stimulates work transitions.

On the other hand, Tomlinson [27] expresses employability in function of capital, which he defines as a series of key resources that grant benefits and advantages to the graduate. These capitals are framed in a set of educational, social, cultural and psychosocial dimensions, which are acquired from diverse experiences.

The acquisition of these experiences for the graduate is focused on a collective source; the university. In this sense, González-Romá, Gamboa, \& Peiró [2], take the model proposed by Fugate, Kinicki, \& Ashforth [28] on employability - whose components are career identity, personal adaptability and human and social capital - and evaluate its applicability in the context of university graduates. Based on this, they carry out a study in which they relate each component of the model with the situation and labour quality, finding that the components of career identity and human and social capital play an important role in the employability of graduates. Based on this, they 
suggest that the university should work to provide guidance and services to stimulate the development of these components in students.

\subsection{TYPES OF SYSTEMS/PROBLEMS}

\subsubsection{Simple problem}

A simple or linear problem complies with a number of principles, such as:

- $\quad$ Principle of causality: This assumes that the future of the system can be determined based on its initial conditions, where it accepts that the interaction between the parts is not significant [17].

- Principle of proportionality: The variation experienced by an input in the system will produce proportional changes in the outputs.

- Principle of superposition: Indicates that the whole is equal to the sum of the parts.

\subsubsection{Complex problem}

A complex problem is characterized by the permanent emergence of behaviors based on the interaction and interdependence of a large number of variables that are difficult to predict and control. Some of the characteristics of complex problems are:

- Self-organization and emergence: Self-organization refers to the emergence of new states of order; collective behaviors from the interaction between the parts [18] [19]. Emergence on the other hand, is manifested in the constant appearance of variations that lead the system to conditions that differ from the initial ones [17].

- Evolution and co-evolution: Evolution is a process of change and transformation, and can be characterized from the global behaviors that arise from the interaction between the parts [20]. Coevolution refers to the mutual adaptation between systems as a result of the reciprocal influence between them.

- Interrelation and interdependence: The parts that make up the system interact with each other in a non-proportional way. 


\section{METHODOLOGY}

The development of this work was based on a review of the literature and panel of experts through structural analysis, as shown in Figure 1.
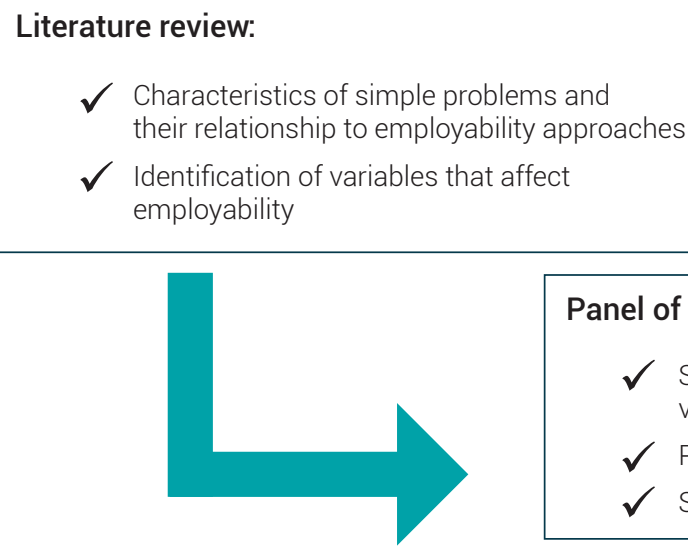

\section{Panel of experts:}

Sufficiency and clarity of the identified variables

$\checkmark$ Possible unidentified variables

$\checkmark$ Structural analysis

Figure 1. Methodology

Source: own work

The review of the literature was carried out with the following objectives:

- $\quad$ Provide evidence that employability, to date, has been addressed as a simple problem. For this purpose, the consulted works are initially categorized according to the adopted approach, for example, if it is an individual or collective approach, by relating each of the variables that are contemplated with a specific actor. After this, the proposals and/or approaches are analyzed, identifying whether they are reductionist and/or linked to one or several principle characteristics of simple problems.

- Based on these approaches, identify the different variables that affect employability and thus adopt the perspective of complex thinking in which the problem is not addressed by studying each of the variables separately, but rather as a whole and including each of the actors that influence the problem.

This review was carried out in the databases of ScienceDirect, SciELO, Redalyc, EBSCOHost and the Google Academic search engine, using the keywords: employability, employability practices, employability competencies, graduate employability, employability factors. 
The identified variables pass to a verification stage through a panel of experts, which is a methodology where different aspects of a topic are evaluated through the joint action of the participants.

The panel was made up of 5 people with different roles, which provided an approach to the subject from different perspectives (business-academic-research) and was developed in three phases, each of these linked to a specific objective:

- Evaluation of the sufficiency and clarity of the definition of the previously identified variables: In the first instance, a socialization is made of the variables that were identified from the review of the literature, providing a definition for them. Subsequently, through brainstorming, the experts presented their point of view and/or concerns regarding some variables, from which it was established if the proposed definition is clear and concise and if it does not adopt a general perspective that leads to the creation of a new variable. As a result of this, a final construction of the definition of each variable is carried out.

- Identification of possible non-contemplated variables: Experts are asked if within the variables previously evaluated, there are aspects that are not included in them and that suggest the creation of new variables. Based on a brainstorming session, it was established that none of the variables included the aspirations of the professional and the conditions in which the companies find themselves to provide job stability; in this way, the life project variables and the capacity of the companies to retain employees are presented.

- Identification of the variables with the greatest impact on employability and the relationship between them through structural analysis, which is developed as follows:

Table 1. Stages of structural analysis

\begin{tabular}{ll}
\hline \multicolumn{1}{c}{ Phase } & \multicolumn{1}{c}{ Description } \\
\hline $\begin{array}{l}\text { Structuring Relationships } \\
\text { Matrix }\end{array}$ & Construction of a cross-impact matrix between the variables studied \\
\hline $\begin{array}{ll}\text { Expert evaluation } & \text { Each expert analyzes the level of direct influence between variable i (located in } \\
\text { the rows) and variable } \mathrm{j} \text { (located in the columns), using a scale from } 0 \text { to } 4, \text { where } \\
\text { 0 does not represent any type of influence and } 4 \text { the highest level of influence. }\end{array}$ \\
$\begin{array}{ll}\text { Calculation of the resulting } \\
\text { matrix }\end{array}$ & \begin{tabular}{l} 
The expert's evaluation is averaged, calculating a resulting matrix. \\
\hline
\end{tabular} \\
\hline
\end{tabular}


(viene)

\begin{tabular}{ll}
\hline \multicolumn{1}{c}{ Phase } & \multicolumn{1}{c}{ Description } \\
\hline $\begin{array}{l}\text { Evaluation of results in the } \\
\text { MICMAC software }\end{array}$ & $\begin{array}{l}\text { The resulting matrix is indexed in the cross-impact matrix of the MICMAC software } \\
\text { in order to facilitate subsequent analysis. }\end{array}$ \\
\hline Results Graph & $\begin{array}{l}\text { Running the MICMAC software gives a graph on a Cartesian plane, which relates } \\
\text { the level of dependence and influence that each variable has on the problem. }\end{array}$ \\
\hline Analysis of results & The results are interpreted according to the location of the variables in the plane. \\
\hline
\end{tabular}

Source: own work based on [21]

The structural analysis is a tool that offers the possibility of characterizing a system by a matrix that relates all the elements that constitute it. The objective is to identify the influential and dependent variables that are key to the evolution of the system. To achieve this, through MICMAC (Impact Matrix Cross-Reference Multiplication. Applied to a Classification ), a direct classification is first performed, which turns out to be easy to perform; and then, an indirect classification is made after the power elevation of the matrix [29].

In the framework of the present paper, the application of the technique is not exactly limited to identifying the key variables of the problem (since it would be reductionist); it is also used with the objective of revealing the importance of other variables to which less interest is given in the literature, as well as evidencing the interrelation existing between the variables.

\section{RESULTS}

This section shows the set of variables that affect employability, identified in the literature review and evaluated by the panel of experts. It should be noted that the review found several projects such as [13] and [14] in which employability is understood in a holistic way, and which was therefore of special help to the present work.

In this line it is important to emphasize that, although holism and complexity have similarities in sharing the idea that a problem must be understood as a whole, they differ in that complexity broadens this conception by taking into account the emergence of changes experienced by the problem from the interaction between a large number of variables that are difficult to predict and control. 


\subsection{Identified variables}

- Competences (COMPT): "A competence is the integration of knowledge, skills, attitudes and values that allows a person to perform effectively in various contexts and adequately perform a function, activity or task"; [36].

- Academic background (F. ACAD): University degree, command of other languages, work experience, congresses, research and extracurricular activities.

- Networking (NW): Contact networks that can facilitate the entry of the graduate into the labor market. [27] refers to these networks as social capital.

- Physical and psychological conditions (C. F. P.): Such as physical health, mental health, and disabilities, which influence a person's job performance.

- Demographic characteristics (C. DEM): Attributes such as gender, age, ethnicity etc. This may influence the motivations of individuals or their ability to carry out certain jobs [13].

- Mobility (MOV): Possibilities that a professional has to move in the internal or external labor market [14].

- $\quad$ Life Project (P. VIDA): "Personal Development Planning"; [23]. Personal and professional aspirations of a graduate influenced by its motivation [28], work identity [28], self-efficacy, self-esteem and self-confidence [23].

- $\quad$ Relevance curriculum (P. EST): Adjustment between what HEls teach and what society/business requires.

- $\quad$ Characteristics IES (C. IES): These are those attributes that highlight and define a higher education institution such as academic character, legal nature (public or private), prestige [45] [46] and relevance of academic offer [1].

- Government Policies (POLT): A set of guidelines established by government to improve the employability of graduates [13].

- Employment promoting organizations (ORG. P. E): Mechanisms developed by different actors for the promotion of employment such as universities that provide guidance services and other organizations such as job boards, alumni associations, etc.

- $\quad$ Absorption capacity (C. ABS): Supply-demand ratio that makes up the labor market. It refers to a country's ability to generate employment under the right conditions, enabling professionals to perform adequately.

- Budget (PSTO): Public resources destined to finance higher education, entrepreneurship and mechanisms that improve the employability of a country. 
- Company Requirements (R. EMP): Applications and requirements that a company considers necessary for the incorporation of a new employee to the organization.

- Economic Situation (S. ECON): Macroeconomic factors (inflation, GDP, unemployment rate, etc.) that a country presents and that determine its economic activities, as well as the economic relations between countries [13].

- Technological Trends (TECN): Incidence of technological advances in the processes carried out in companies and in the behavior of society.

- Society/Culture (S/C): Patterns of behavior of a set of people that include beliefs, values, morals, rules, and social prejudices.

- $\quad$ Research, development, innovation ( $1+\mathrm{D}+\mathrm{i})$ : These are fundamental pillars for the development of the country (indeed for education in general) for the promotion and creation of new jobs.

- $\quad$ Ease of access to resources (F. REC): Refers to the conditions of infrastructure and finance (transport, food, access to technology, etc.) in which the potential used to access the benefits of work is found [13].

- Synergy of actors (S. ACT): Joint action of all actors (Professionals, Government, University, Enterprise, Society) that help to improve employability.

- $\quad$ Ability of enterprises to retain employees (CEE): Ability of enterprises to offer employment conditions that are attractive to employees, such as wages offered, incentives etc. and thus retain them.

\section{DISCUSSION}

\subsection{Employability as a simple problem: reductionism, principles of proportionality, causality and superposition:}

It can be seen that the literature on employability tends to lean towards those variables that are closely related to the individual [13] [14] [30]. It is common to find that several authors focus on the importance of competencies in the employability of professionals [31]-[39] based on the idea that certain competencies allow professionals to move and adapt effectively in the labor market [28] [47]. 
Although this conception is linked to one of the characteristics of the problem, focusing only on this aspect leads one to think that the more a graduate possesses a greater number of competences, the more employable they will be (principle of proportionality) or that the high employability of a professional is strictly due to the competences he or she possesses (principle of causality).

The principles of proportionality and causality may also be evident in the following considerations:

- The conclusion reached [40] after a literature review indicates that there is really no lack of work, but that there is a gap between what is taught and what should be learned.

- Consider the university as the main agency for promoting employability [34] and with this link employability as an indicator of the quality of higher education [41] [42].

- [3] explains that weak employability is due to insufficient training and its inadequacy to the characteristics of the job (vocational guidance).

- Employability has become one of the pillars of the new educational model, promoting a teaching-learning model aimed at obtaining competences [43].

Although these points turn out to be fundamental in the problem, they lead to the adoption of a simplistic vision in which the mismanagement of HEls is taken as the main cause, both in the training process and in the services offered to favor the insertion of graduates into the labor market. Thus, in the literature it is found that the various alternatives for improving employability tend to emphasize the actions that HEls should carry out, with the appropriate configuration of curricula and pre-professional practices being the most common, in order to promote the development of competences.

Although there are several investigations that support these proposals, they are insufficient since they do not cover a large part of the contextual variables that affect the problem. Moreover, due to the unilateral perspective from which they are formulated, they are not adequately implemented. In the case of pre-professional practices, the tasks carried out in these are often not related to the training area, thus misaligning their objective [44].

In this line, it is easy to note that there is a disarticulation between university-industry in the implementation of these alternatives, which is accentuated by 
government action, since the structuring of employment policies are directed towards solutions that focus on the individual [13].

A number of approaches can also be found in which the view of employability is broadened to include other aspects in addition to skills; however, the variables presented in these are still limited. An example of this is the Career EDGE model [23], the overview of which can be described in the following idea: The development of $X$ (knowledge, understanding and skills + generic competences + emotional intelligence + career development learning + work experience and life) in students leads to them adopting a state $Y$ (reflection and evaluation) which in turn helps them to develop $Z$ (self-efficacy + self-confidence + self-esteem ) and thus achieve higher levels of employability.

As is to be noted, causality is one of the main characteristics of this model. It also leads one to think that the extent to which a student is allowed to develop these attributes will proportionally impact their employability.

With regard to the principle of superposition, the various approaches found in the literature present the problem of employability as a set of sub-problems that can be addressed independently. In this sense the competency-based approach (being the most common and simplistic) can be expressed as follows:

$$
\text { Employability=hard skills }+ \text { soft skills }
$$

\subsection{The complexity of the employability problem:}

According to the findings found in the structural analysis carried out by the panel of experts, as can be seen in Figure 1, the location of the variables in the plane's bisector occurs in this order: mobility, networking, company requirements, economic situation, life project, I+D+i and skills, indicating that they have a high level of influence on the problem of employability. In this sense, it is easy to demonstrate the level of importance of context variables, which have been neglected in the approaches found in the literature, supporting the perspectives of authors such as [13] and [14]. Along these lines, the importance of the role played by the multiple actors that influence employability can be seen, confirming the idea that it is incorrect to attribute a large part of the responsibility to only one of them.

On the other hand, government policies and synergy of actors can be catalogued as power variables, which are characterized by a high influence with a low degree of dependence. This shows that it is extremely important that the structuring of policies that can affect employability is the result of synergic work between actors. 
The variables budget, demographic characteristics and ease of access to resources are also located in the power variables area. However, it can be observed that they have a lower level of influence in relation to the political variables and synergy of actors.

The study plan variable is located in a transition zone and so it is not possible to make a concise classification of it. However, it can be observed that this has a medium level of influence and is influenced in a low proportion by the other variables. According to this and based on the review of the literature it could be thought that this variable could be characterized as a power variable, due to the impact it has on the training of professionals to respond to the needs of companies/society and contribute to activities of $\mathrm{I}+\mathrm{D}+\mathrm{i}$.

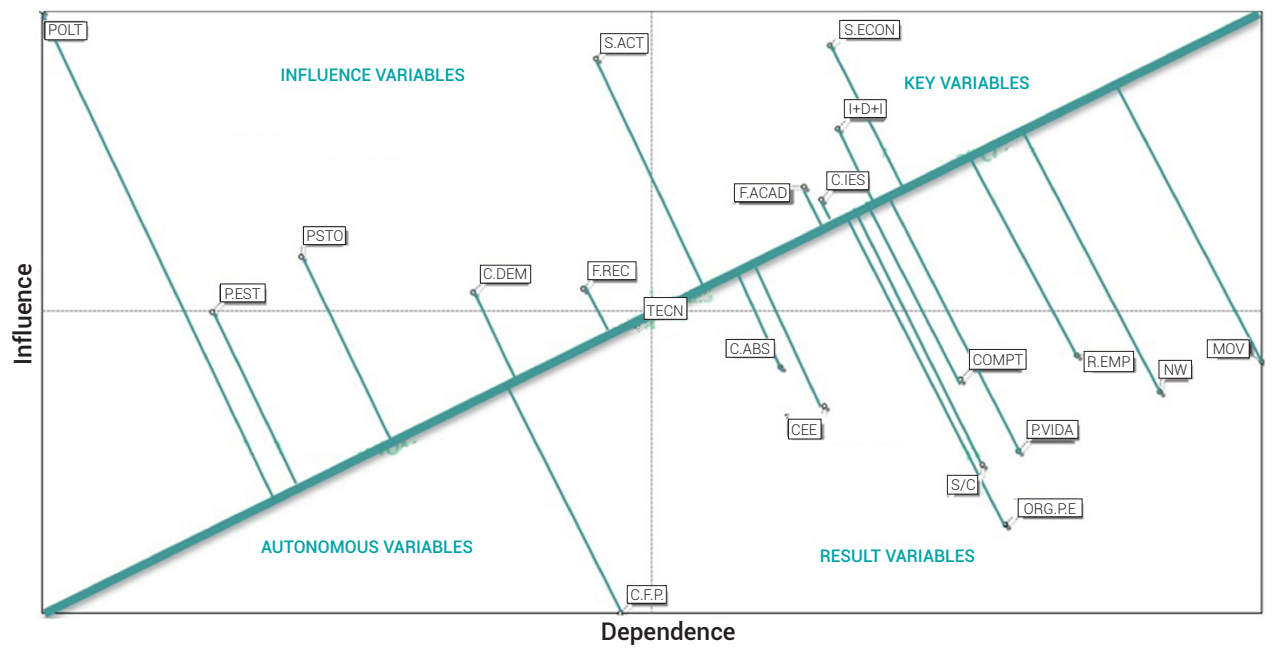

Figure 2. Plan of direct influences/dependencies Source: own work

As far as competences are concerned, although these play an important role in the problem, it is clear that there are other variables that have a higher level of relevance; especially contextual variables, such as the economic situation or the research activities of a country. These have a notable impact on the behavior of the labor market, making it clear that it is inappropriate to focus employability on the development of competencies.

Finally, Figure 3 clearly shows the high degree of interdependence between the variables that affect employability which, added to the different levels of connectivity and the non-linear influence between them, causes the problem to remain in a constant state of change, supporting the demonstration of its complex nature. 


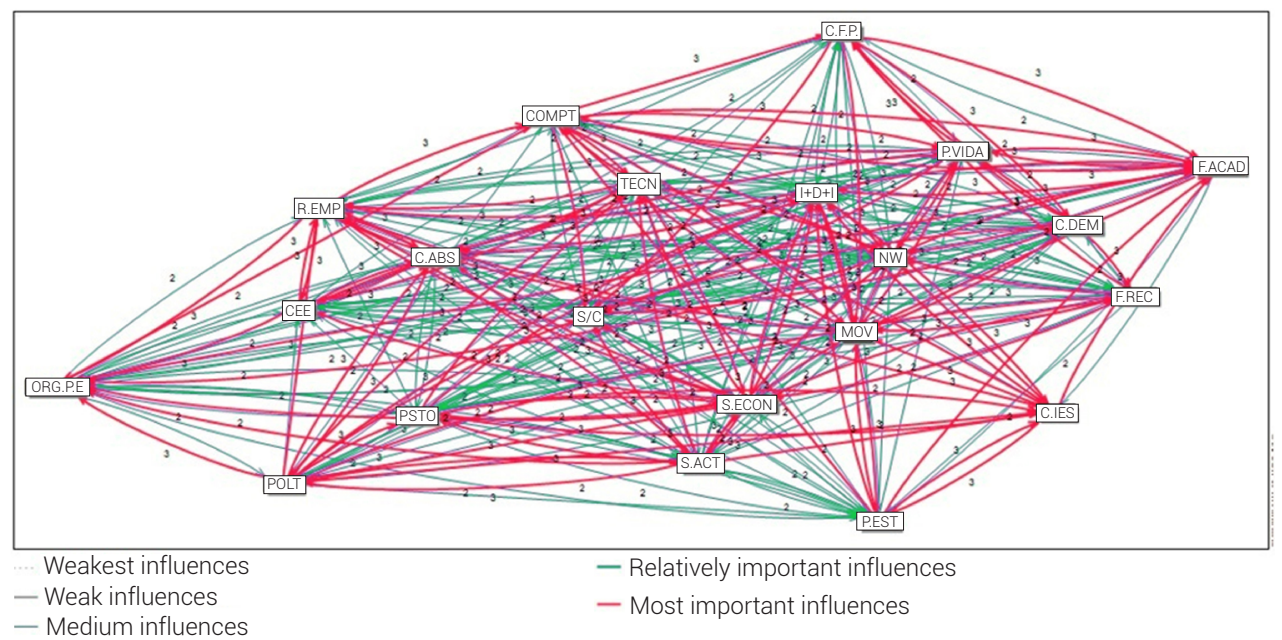

Figure 3. MICMAC Direct Influence Chart Source: own work

\section{CONCLUSIONS}

The results found, although partial, allow us to assume that employability is an emerging result of the articulation of diverse actors, variables and contexts; that it requires a reconsideration of the predominant approach that has been given so far, in which its complexity is recognized. This leads to rejecting the idea that employability can be reduced to a set of variables that can be studied in isolation.

This does not imply that the reductionist approaches found in the review lose their validity, but rather that they become an input for the construction of new proposals or improvement of existing ones. Under the proposed approach, the responsibility for employability given to professionals and HEls is lightened, but this does not mean that their importance in the problem is also lightened.

It is necessary that the different actors work together and create mechanisms that allow a constant interaction between them, so that there is a continuous flow of information that allows them to act in an articulated manner and in line with the objectives set for improving employability, generating alternative solutions adaptable to different contexts.

The implementation of this change of perspective requires rigorous work and implies the adoption of new paradigms imposed by complex thinking, which are currently the subject of research. In this sense, the use of innovative tools such as the modeling and simulation of complex systems are fundamental. 
These tools extend the knowledge about the characteristics of a system, in which due to its complexity, they are not easy to observe in its totality. Therefore, as future lines of research, the study of the employability problem through these tools is proposed in order to validate the variables identified in the present work and their degree of influence in multiple scenarios.

\section{REFERENCES}

[1] C. Rodríguez and V. Castillo, "Empleabilidad, ingresos y brechas: Un análisis comparativo de los procesos de inserción laboral en Chile," Orientación y Soc., vol. 14, 2014. [Online]. Available: http://www.scielo.org.ar/pdf/orisoc/v14/v14a04.pdf

[2] V. González-Romá, J. P. Gamboa, and J. M. Peiró, "University Graduates’ Employability, Employment Status, and Job Quality," J. Career Dev., vol. 45, no. 2, pp. 132-149, 2018. [Online]. doi: https://doi.org/10.1177/0894845316671607

[3] N. García, "La empleabilidad: competencia y formación," Rev. Postgrado FACE-UC, vol. 6, pp. 263-272, 2012. [Online].Available:http://www.arje.bc.uc.edu.ve/arj10/art15.pdf

[4] M. Tomlinson, "Graduate employability: A review of conceptual and empirical themes," High. Educ. Policy, vol. 25, no. 4, pp. 407-431, 2012. [Online]. doi: https://doi.org/10.1057/ hep.2011.26

[5] D. Herrera Cuesta, "Empleabilidad versus sobrecualificación. Desajuste entre formación y empleo en las trayectorias laborales de los jóvenes titulados en España," Sociol. del Trab., no. 89, pp. 29-52, 2017. [Online]. Available : https://revistas.ucm.es/index.php/STRA/article/ view/59635/4564456546827

[6] P. Brown, A. Hesketh, and S. Wiliams, "Employability in a Knowledge-driven Economy," J. Educ. Work, vol. 16, no. 2, pp. 107-126, 2003. [Online]. doi: https://doi. org/10.1080/1363908032000070648

[7] S. Aránega, "Competencias para la empleabilidad ¿Cómo desarrollarlas en la educación superior?," Procedia - Soc. Behav. Sci., vol. 139, pp. 366-372, 2014. [Online]. doi: https://doi. org/10.1016/j.sbspro.2014.08.015

[8] S. Kalfa and L. Taksa, "Cultural capital in business higher education: reconsidering the graduate attributes movement and the focus on employability," Stud. High. Educ., vol. 40, no. 4, pp. 580-595, 2015. [Online]. doi: https://doi.org/10.1080/03075079.2013.842210 
[9] T. T. Tran, "Is graduate employability the 'whole-of-higher-education-issue'?," J. Educ. Work, vol. 28, no. 3, pp. 207-227, 2015. [Online]. doi: https://doi.org/10.1080/13639080.2014. 900167

[10] F. E. Bara, "¿Es la empleabilidad un fin de la Educación Superior? Concepciones encontradas," Procedia - Soc. Behav. Sci., vol. 139, pp. 110-115, 2014. [Online]. doi: https://doi.org/10. 1016/j.sbspro.2014.08.036

[11] B. S. Lantarón, “Empleabilidad: análisis del concepto," vol. 14, no. 1, pp. 67-84, 2016. [Online]. Available:https://www.researchgate.net/publication/303686234_Empleabilidad _analisis_del_concepto

[12] J. Hillage and E. Pollard, "Employability: developing a framework for policy analysis," Labour Mark. Trends, vol. 107, no. 85, pp. 83-84, 1999. [Online]. Available: https://www.education.gov.uk/publications/eOrderingDownload/RB85.pdf

[13] R. W. McQuaid and C. Lindsay, "The Concept of Employability," Urban Stud., vol. 42, no. 2, pp. 197-219, Feb. 2005. [Online]. doi: https://doi.org/10.1080/0042098042000316100

[14] A. Forrier and L. Sels, "The concept employability: a complex mosaic," Int. J. Hum. Resour. Dev. Manag., vol. 3, no. 2, pp. 102-124, 2003. [Online]. doi:https://doi.org/10.1504/ IJHRDM.2003.002414

[15] L. Small, K. Shacklock, and T. Marchant, "Employability: a contemporary review for higher education stakeholders," J. Vocat. Educ. Train., vol. 70, no. 1, pp. 148-166, 2018. [Online]. doi: https://doi.org/10.1080/13636820.2017.1394355

[16] P. Brown, A. Hesketh, and S. Wiliams, The mismanagement of talent: Employability and jobs in theknowledge economy, Oxford, Oxford University Press, 2004.

[17] K. Cepeda, K. Durango, and L. Bohórquez, "Modelación y simulación basada en agentes como alternativa para el estudio de las organizaciones empresariales," Ing. Solidaria, vol. 13, no. 22, pp. 103-119, 2018. [Online]. doi: https://doi.org/10.16925/in.v13i22.1838

[18] G. Di Marzo Serugendo, M. Gleizes, and A. Karageorgos, Self-organising Software:From Natural to Artificial Adaptation. 2011. [Online]. doi: https://doi.org/10.1007/978-3-642-17348-6

[19] E. Bonabeau, G. Theraulaz, J. L. Deneubourg, S. Aron, and S. Camazine, "Selforganization in social insects," Trends Ecol. Evol., vol. 12, no. 5, pp. 188-193, 1997. [Online]. doi: https://doi.org/10.1016/S0169-5347(97)01048-3 
[20] L. Bohórquez, "Understanding of Business Organizations and their Environment as Systems of Increasing Complexity: Features and Implications," vol. 21, pp. 363-377, 2016.[Online]. doi:https://doi.org/http://dx.doi.org/10.14483/udistrital.jour.reving.2016.3.a07

[21] Y. Suárez, L. Suárez, and L. Bohórquez, "Emergencia De La Cooperacion En Las Organizaciones Empresariales: Condiciones Requeridas," vol. 3, pp. 493-504, 2016. [Online]. Available: https://proceedings.ciaiq.org/index.php/ciaiq2018/article/view/1943/1892

[22] P. Knight and M. Yorke, "Employability Through the Curriculum Abstract.," Pretoria, Dep. Educ., vol. Volume 8, no. 4, pp. 261-276, 2002. [Online]. doi: https://doi.org/10.1023/A: 1021222629067

[23] L. Dacre Pool and P. Sewell, "The key to employability: developing a practical model of graduate employability,” Educ. + Train., vol. 49, no. 4, pp. 277-289, Jun. 2007. [Online]. doi: https://doi.org/10.1108/00400910710754435

[24] M. Fugate. Employability. In J. Greenhaus and G. Callanan (Eds.), Encyclopedia of career development Thousand Oaks., vol.1, pp267-271 ,2006.

[25] M. Fugate and A. J. Kinicki, "A dispositional approach to employability: Development of a measure and test of implications for employee reactions to organizational change," J. Occup. Organ. Psychol., vol. 81, no. 3, pp. 503-527, 2008. [Online]. doi: https://doi. org/10.1348/096317907X241579

[26] A. Forrier, M. Verbruggen, and N. De Cuyper, "Integrating different notions of employability in a dynamic chain: The relationship between job transitions, movement capital and perceived employability," J. Vocat. Behav., vol. 89, pp. 56-64, 2015. [Online]. doi: https://doi.org/10.1016/j.jvb.2015.04.007

[27] M. Tomlinson, "Forms of graduate capital and their relationship to graduate employability," Educ. + Train., vol. 59, no. 4, pp. 338-352, Apr. 2017. [Online]. doi: https://doi.org/10.1108/ ET-05-2016-0090

[28] M. Fugate, A. J. Kinicki, and B. E. Ashforth, "Employability: A psycho-social construct, its dimensions, and applications," J. Vocat. Behav., vol. 65, no. 1, pp. 14-38, Aug. 2004. [Online]. doi: https://doi.org/10.1016/j.jvb.2003.10.005

[29] M. Godet, La caja de herramientas de la prospectiva estratégica, 2000. [Online]. Available: http://centrolindavista.org.mx/archivos_index/caja_de_herramientas.pdf\%0A 
[30] J. G. L. Thijssen, B. I. J. M. Van Der Heijden, and T. S. Rocco, "Toward the employability-link model: Current employment transition to future employment perspectives," Hum. Resour. Dev. Rev., vol. 7, no. 2, pp. 165-183, 2008. [Online]. doi: https://doi.org/10.1177/1534484308314955

[31] M. Yorke, "Employability in higher education: what it is - what it is not," Enhancing Student Employab. Co-ord. Team, 2006. [Online]. Available: https://www.researchgate.net/ publication/225083582_Employability_in_Higher_Education_What_It_Is_What_It_Is_Not

[32] M. del C. Aguilar Rivera, L. Villardón, M. Álvarez, Á. Moro, I. Elexpuru, and C. Y. Álvarez de Eulate, "Perceived Employability and Competence Development," Procedia - Soc. Behav. Sci., vol. 69, no. Iceepsy, pp. 1191-1197, 2012. [Online]. doi: https://doi.org/10.1016/j. sbspro.2012.12.051

[33] J. Secanella, "Nuevas competencias para la empleabilidad de los estudiantes universitarios," La cuestión Univ., no. 7, pp. 40-47, 2011. [Online]. Available: http://polired.upm.es/index.php/ lacuestionuniversitaria/article/view/3357/3422

[34] J. Argos and P. Ezquerra, "Universidad y competencias para la empleabilidad," Procedia - Soc. Behav. Sci., vol. 139, pp. 290-296, 2014. [Online]. doi: https://doi.org/10.1016/j. sbspro.2014.08.002

[35] M. del C. O. Navas, "La mejora de la empleabilidad en los estudiantes de Educación Superior: el uso de la inteligencia emocional como estrategia educativa," Procedia - Soc. Behav. Sci., vol. 139, pp. 380-386, 2014. [Online]. doi: https://doi.org/10.1016/j.sbspro.2014.08.021

[36] A. Rodríguez, "La formación universitaria en competencias: Incidencia En La Evaluación Pedagógica De Los Procesos De Enseñanza - Aprendizaje Desde El Enfoque Socioformativo," vol. 15, 2016. [Online]. Available: https://buleria.unileon.es/bitstream/handle/10612/6224/ Rodriguez\%20Esteban.pdf?sequence=1

[37] B. Fernández, "Competencias laborales y de empleabilidad en la educación vocacional," Calid. en la Educ., vol. 27, pp. 36-52, 2007. [Online]. doi: https://dx.doi.org/10.31619/caledu. n27.217.

[38] J. Jover, Valdes, A. Trapote, and M. Pardo, "Empleabilidad en la Ingeniería Civil. Fortalezas y debilidades desde el punto de vista de alumnosy egresados," pp. 2-6,2015. [Online]. Available https://rua.ua.es/dspace/bitstream/10045/49968/2/XIII_Jornadas_Redes_219_poster.pdf

[39] L. Arias Montoya, L. Portilla de Arias, and M. Flores de Trujillo, "Competencias y empleabilidad.," Sci. Tech., vol. 5, no. 37, pp. 379-382, 2007. [Online]. doi: https://doi. org/10.22517/23447214.4125 
[40] J. García, "Why do they Call it Education when they Mean... Employability? On the Concept of Utility in Education," Procedia - Soc. Behav. Sci., vol. 139, pp. 102-109, 2014. [Online]. doi: https://doi.org/10.1016/j.sbspro.2014.08.034

[41] N. Orellana, Consideraciones sobre empleabilidad en educación superior, pp. 273-291, 2018. [Online]. doi:http://dx.doi.org/10.31619/caledu.n48.477

[42] L. A. Støren and P. O. Aamodt, "The quality of higher education and employability of graduates," Qual. High. Educ., vol. 16, no. 3, pp. 297-313, 2010. [Online]. doi: https://doi.org/10. 1080/13538322.2010.506726

[43] F. Michavila, J. M. Martínez, M. Martín, F. J. García, and J. Cruz, "Empleabilidad de los titulados universitarios en España. Proyecto OEEU,” Educ. Knowl. Soc., vol. 19, no. 1, p. 21, 2018. [Online]. doi: https://doi.org/10.14201/eks20181912139

[44] D. Prieto, N. Manzano, and M. de J. Villalón, "Prácticas profesionales virtuales como estrategia de empleabilidad: el caso de la UNED," vol. 28, pp. 122-138, 2017. [Online]. doi: http://dx.doi. org/10.5944/reop.vol.28.num.2.2017.20124

[45] O. Geeregat Vera, G. Cifuentes Gómez, and M. C. Villarroel Farías, "Factores que inciden en las condiciones de empleabilidad de los egresados en pedagogía," Actual. Investig. en Educ., vol. 16, no. 1, pp. 1-19, Jan. 2016. [Online]. doi: https://doi.org/10.15517/aie.v16i1.21935

[46] S. Power and G. Whitty, "Graduating and gradations within the middle class: the legacy of an elite higher education,” pp. 119-128, 2008. [Online]. Available: http://orca.cf.ac.uk/ 25005/1/wp118.pdf

[47] M. Clarke, "Understanding and Managing Employability in Changing Career Contexts," Journal of European Industrial Training, vol 32, no 4, pp. 258-284, 2008. [Online]. doi: https:// doi:10.1108/03090590810871379. 